\title{
INFORMATIZACIJA ARHIVSKIH EVIDENCIJA U DRŽAVNOM ARHIVU U PAZINU
}

\author{
Sebastijan LEGOVIĆ \\ UDK 004.651:930.255>(497.571)(091) \\ Državni arhiv u Pazinu \\ Stručni rad \\ Pazin, Vladimira Nazora 3 \\ DOI https://doi.org/10.31726/via.25.3 \\ sebastijan.legovic@dapa.hr
}

U Državnom arhivu u Pazinu arhivske se evidencije vode još od 1962. godine. Novi arhivski propisi vezani uz vođenje evidencija stupaju na snagu 1997. i 2002. godine. Uočavajući prednosti informatizacije, u DAPA se u nekoliko navrata pokušalo uvesti informatizirani način vođenja evidencija.

Ključne riječi: propisi, evidencije u arhivu, informatizacija, baze podataka, aplikacija

Keywords: rules and regulations, record keeping in archives, informatisation, databases, application

Parole chiave: regolamenti, registrazioni nell'archivio, informatizzazione, basi di dati, applicazione

\section{Uvod}

Danas se arhivske evidencije vode s ciljem uspješnog obavljanja svih djelatnosti arhiva ${ }^{1}$ propisanih zakonskom regulativom. U SR Hrvatskoj 60-ih godina prošlog stoljeća dolazi do uspostave mreže javnih državnih arhiva. Prvi propis o obaveznom vođenju evidencija, odnosno Uputstvo o vođenju evidencije u arhivima² donesen je 1963. godine. Tim propisom arhivi su bili obavezni voditi sljedeće evidencije: Knjigu primljene arhivske građe, Opći inventar arhivske građe, Inventare za pojedine fondove i zbirke te Vodič kroz arhivsku građu. Vođenje evidencija je kasnije propisano i Zakonom o zaštiti arhivske građe i arhivima iz $1965 .{ }^{3}$ te 1978 . godine. ${ }^{4}$

\section{Arhivske evidencije u Državnom arhivu u Pazinu}

U Državnom arhivu u Pazinu (dalje: DAPA), odnosno tadašnjem Historijskom arhivu Pazin poslovi vođenja evidencija započinju već 1962. godine gdje se u izvještaju o radu arhiva navodi da Vodič kroz arhivsku građu sadrži više podataka tako da je rad na ovoj evidenciji tek započet. U izvještajima o radu arhiva od šezdesetih pa sve do kraja devede-

Kada se u ovom radu govori o arhivima misli se na javne državne arhive.

Narodne novine (dalje: NN) 21/1963.

$3 \quad \mathrm{NN} 31 / 1965$.

$4 \quad$ NN 25/1978. 
setih godina prošlog stoljeća navodi se ažurno vođenje raznih evidencija kao što su: Opći inventar arhivske građe i Knjiga primljene arhivske građe (slika 1.), Vodič kroz arhivsku građu, Kartotečni popis registratura, Matični listovi i dosjei registratura, Rokovnik mjera, Pregled škartiranja po registraturama, Evidencija vanjske službe za slučaj izvanrednih mjera i Evidencija građe izvan arhiva, Dnevnik spremišta, Evidencija o radu u čitaonici, te Knjiga inventara. Sve navedene evidencije vodile se u konvencionalnom obliku. ${ }^{5}$

$\mathrm{S}$ vremenom su se osobna računala počela sve više koristiti u radu u DAPA. Uočavajući prednosti informatizacije, u nekoliko se navrata pokušalo uvesti informatizirani način vođenja evidencija. Tako se 1990. godine u izvještaju o radu navodi da je krajem godine instaliran slovenski arhivistički program ARMIDA. To je bio računalni program za sve evidencije koje se vode u arhivu: Pregled fondova i zbirki (s osnovnim podacima o fondu), Evidencija registratura, Evidencija mikrofilmiranog gradiva i Evidencija fondova u drugim arhivima. No, u daljnjim izvještajima rada više se navedeni program ne spominje. Isto tako, 1992. godine u izvještaju o radu navodi se da se evidencije u čitaonici (Evidencija znanstvenika i korisnika gradiva, Evidencija korištenja gradiva, Evidencija dopreme gradiva u čitaonicu i otpreme istog iz čitaonice u spremište i Evidencija tema) vode »računalno«.
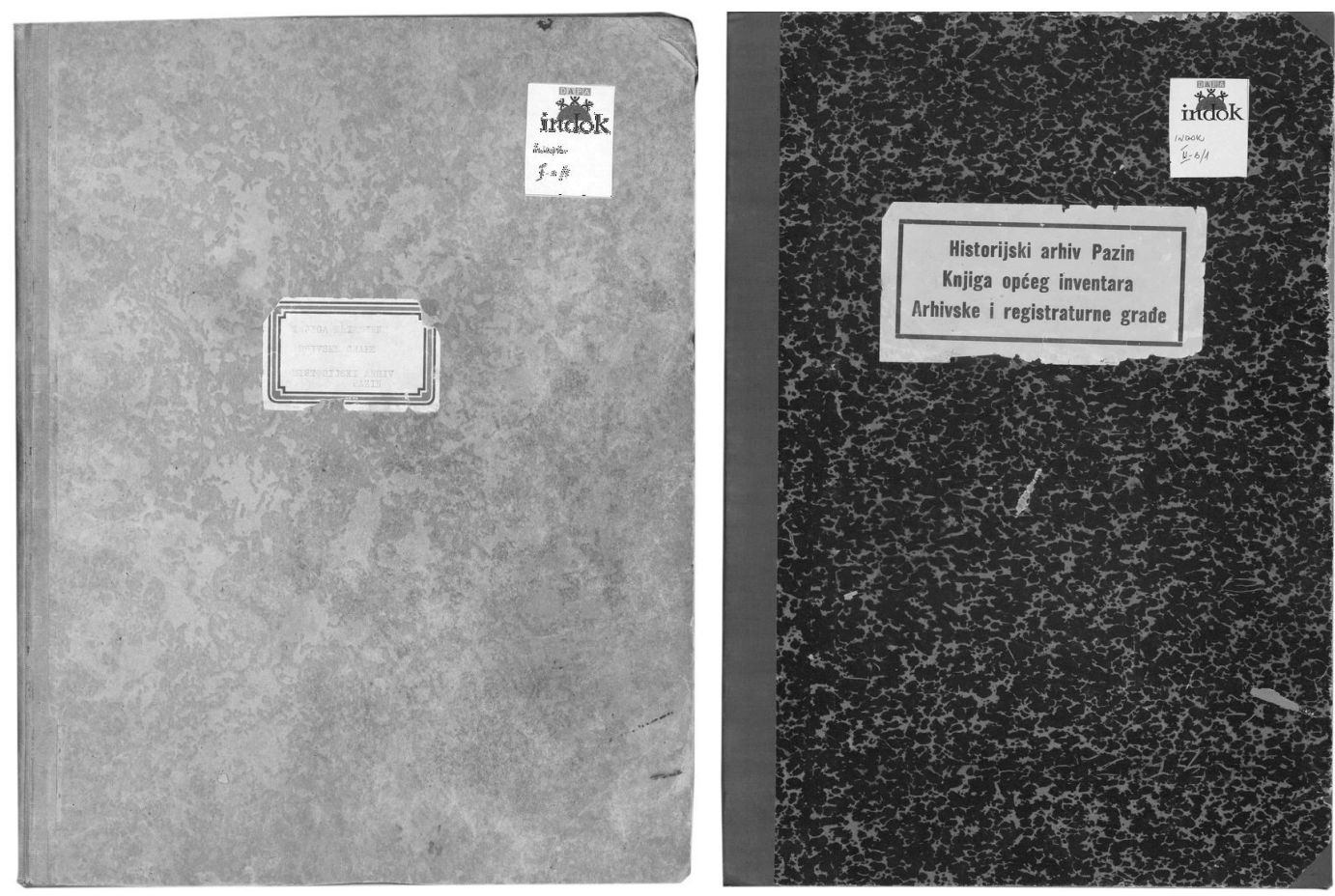

Slika 1. Knjiga primljene arhivske građe i Opći inventar arhivske građe

\footnotetext{
5 Ručnim unosom podataka u knjige.
} 
Donošenjem nove zakonske regulative 1997. godine, odnosno Zakona o arhivskom gradivu i arhivima (dalje: Zakon), ${ }^{6}$ a posebno Pravilnika o evidencijama u arhivima 2002. godine (dalje: Pravilnik) ${ }^{7}$ nastavlja se kontinuitet obaveznog vođenja evidencija u arhivima. ${ }^{8}$ U članku 47. Zakona i članku 3. Pravilnika propisuje se obavezno vođenje sljedećih evidencija: Knjiga primljenog arhivskoga gradiva (dalje: Knjiga akvizicija), Knjiga pohranjenog arhivskoga gradiva (dalje: Knjiga depozita), Opći inventar (našastar) arhivskoga gradiva (dalje: Opći inventar), Dosje arhivskoga fonda/zbirke, Knjiga arhivskoga gradiva snimljenog u sigurnosne i zaštitne svrhe (dalje: Knjiga snimljenoga gradiva), Knjiga arhivskoga gradiva snimljenog u dopunske svrhe (dalje: Knjiga dopunskih preslika), Knjiga restauriranog i konzerviranog arhivskoga gradiva (dalje: Knjiga restauriranoga gradiva), Evidencija stvaratelja arhivskoga gradiva na području nadležnosti arhiva (dalje: Evidencija stvaratelja), Evidencija imatelja arhivskoga gradiva na području nadležnosti arhiva (dalje: Evidencija imatelja) te Evidencije o korištenju arhivskoga gradiva (dalje: Evidencije o korištenju). ${ }^{9}$

Godine 2000. u DAPA započinje rad na unosu podataka o arhivskim fondovima i zbirkama u bazu podataka »Registar fondova« u programu Microsoft Access ${ }^{10}$, odnosno središnju evidenciju arhivskog gradiva koju vodi Hrvatski državni arhiv (dalje: HDA). Prema izvještaju o radu iz te godine, podatke u bazu unosili su djelatnici DAPA, a nakon unosa podaci su redovito dostavljani u HDA. Tek 2003. godine, nakon primopredaje ravnatelja DAPA, obavljena je revizija svih poslova vezanih uz vođenje evidencija. U izvještaju o radu za tu godinu navodi se da je za većinu evidencija uočeno da uopće nisu vođene ili nisu vođene u skladu sa Zakonom i Pravilnikom, te da je u 2004. godini planirano sustavno obnavljanje svih evidencija. Za evidencije koje su redovito vođene navodi se da ih se namjerava modernizirati i prilagoditi novom Pravilniku. Iste godine šest je stručnih djelatnika DAPA radno sudjelovalo na tečaju stručnog usavršavanja djelatnika u HDA na temu »Primjena novog pravilnika o evidencijama u arhivima« od 14. do 16. svibnja.

Od 2004. do 2006. godine radi se na ažuriranju podataka o arhivskim fondovima i zbirkama za objavu u izdanju Pregled arhivskih fondova i zbirki Republike Hrvatske. ${ }^{11}$ Zbog pogrešnih i/ili nedostajućih podataka koji su bili potrebni za navedeno izdanje, bilo je potrebno pregledati stanje u spremištima, odnosno izvršiti izravni uvid u arhivsko gradivo. Na taj su način dobiveni točni ili barem zadovoljavajući podaci, pa se usporedno ažuriralo i podatke u evidencijama.

\footnotetext{
NN 105/1997.

NN 90/2002.

Neke evidencije su izmijenjene ili ukinute, a Pravilnikom se navodi obavezno vođenje i novih evidencija.

Pravilnikom o izmjenama i dopunama Pravilnika o evidencijama u arhivima (NN 106/2007) vođenje evidencije Dosje arhivskih fondova/zbirki više nije bilo obavezno, ali se u DAPA nastavilo s njegovim vođenjem iste do danas.

10 Microsoft Access je manji sustav za upravljanje bazom podataka. Preuzeto s: http://www.efos.unios.hr/ baza-podataka-i-poslovni-procesi/wp-content/uploads/sites/233/2013/04/BP_Access.pdf (26.2.2018.)

11 Pregled arhivskih fondova i zbirki Republike Hrvatske: Svezak 1, Hrvatski državni arhiv, Zagreb 2006.
} 


\section{Informatizacija vođenja arhivskih evidencija}

Prvi pokušaj informatizacije načina vođenja evidencija prema novim propisima započinje 2004. godine kada se u DAPA zapošljava arhivist-informatičar koji izrađuje aplikaciju »Baza podataka za vođenje evidencija DAPA« preko koje se mogu voditi sve zakonom propisane evidencije. ${ }^{12}$ Aplikacija je bila smještena na poslužitelju DAPA, a pristupalo joj se preko lokalne mreže. Korištene tehnologije za izradu navedene aplikacije bile su Active Server Pages ${ }^{13}$ i baza podataka Microsoft Access. Podaci iz baze $»$ Registar fondova« uključeni su 2005. godine u aplikaciju »Baza podataka za vođenje evidencija DAPA«. ${ }^{14} \mathrm{Krajem}$ iste godine izrađen je nacrt nove baze podataka koji se koriste u evidencijama DAPA, odnosno specifikacija svih podataka koji se koriste u temeljnim arhivskim evidencijama te nacrt strukture baze. ${ }^{15}$

Zbog problema s poslužiteljem, u 2007. godini podaci iz aplikacije »Baza podataka za vođenje evidencija DAPA ${ }^{16}$ uključeni su u radne listove programa Microsoft Excel, ${ }^{17}$ pa se Knjiga akvizicija, Opći inventar i Evidencije o korištenju ${ }^{18}$ vode u elektroničkom obliku u navedenom programu. $U$ istom programu izrađene su i pomoćne evidencije Upisnik obavijesnih pomagala (za unos podataka o obavijesnim pomagalima) i Upisnik dosjea fondova (za evidentiranje dokumentacije koja je bila uložena u pojedini dosje). Evidencija snimljenog gradiva i Evidencija dopunskih preslika vode se u konvencionalnom obliku u Knjizi inventara, a Knjiga restauriranoga gradiva u konvencionalnom obliku u Knjizi evidencije. Iste godine započet je i rad u središnjoj evidenciji arhivskog gradiva na području Republike Hrvatske - Nacionalnom arhivskom informacijskom sustavu, ${ }^{19}$ pa se Evidencija stvaratelja i Evidencija imatelja vode u navedenom sustavu. Uz Evidenciju gradiva posuđenog iz spremišta, ${ }^{20}$ koja se vodila u konvencionalnom obliku i ranijih godina, izrađene su i pomoćne evidencije: Evidencija gradiva posuđenog iz spremišta mikrofilmova, Evidencija gradiva posuđenog iz spremišta - matične knjige i Evidencija gradiva posuđenog iz trezora. Uz Evidenciju o temperaturi i relativnoj vlažnosti u spremištu arhivskog gradiva koja se i ranije vodila u konvencionalnom obliku izrađena je ista evidencija i za spremi-

12 Osim Evidencije stvaratelja i Evidencije imatelja koje nisu bile izrađene.

13 ASP je standardizirani programski jezik za izradu internetskih aplikacija smještenih na Windows platformi. Preuzeto s: https://www.poslovni-software.com/ict-rjecnik/asp-active-server-pages/7/ (26.2.2018.).

14 Treba napomenuti da su samo Knjiga akvizicija i Opći inventar vođeni preko aplikacije »Baza podataka za vođenje evidencija DAPA«, dok su se ostale evidencije nastavile voditi u konvencionalnom obliku. $U$ rujnu 2005. arhivist-informatičar prestaje raditi u DAPA, a ostali djelatnici DAPA nisu bili educirani za održavanje navedene baze.

15 Navedena baza trebala je biti izrađena uz pomoć vanjskih suradnika, ali navedeni projekt nikad nije »zaživio«.

16 Podaci su bili uneseni samo u Opći inventar i Knjiga akvizicija.

17 Microsoft Excel je program za proračunske tablice koji je razvio Microsoft. Preuzeto s: http://www. oblakznanja.com/2011/12/sto-je-microsoft-excel/ (26.2.2018.)

18 Dva zasebna radna lista: jedan za Evidencija korisnika i jedan za Evidencija korištenja. Podaci s obrazaca koji se vode u čitaonici prepisivani su jednom mjesečno u evidenciju u elektroničkom obliku.

19 Sustav je dostupan na mrežnoj adresi: http://arhinet.arhiv.hr/. U sustav su inicijalno na razini države uključeni svi podaci iz ranije spomenute baze podataka »Registar fondova«.

20 Evidenciju vode skrbnici zasebno za svako spremište. 
šte mikrofilmova i digitalnih kopija. Godine 2008. nabavljen je i stavljen u funkciju novi poslužitelj DAPA. Iste godine započinje se s vođenjem Knjige depozita u elektroničkom obliku $^{21}$ (evidencija do tada nije postojala). Kako bi se evidentirali poslovi na digitalizaciji arhivskog gradiva iste godine je izrađena i pomoćna evidencija Upisnik digitalnih presli$k a .^{22}$ Od 2009. godine sve evidencije koje se vode u elektroničkom obliku bile su dostupne djelatnicima DAPA preko zajedničke mape na poslužitelju. ${ }^{23}$ Godine 2010. započeto je $\mathrm{s}$ prepisivanjem podataka o snimljenom, odnosno mikrofilmiranom gradivu iz evidencija koje su se vodile u konvencionalnom obliku. Za te potrebe izrađene su evidencije Knjiga snimljenoga gradiva i Knjiga dopunskih preslika u elektroničkom obliku. ${ }^{24}$ Radne verzije navedenih evidencija bile su također dostupne djelatnicima preko zajedničke mape na poslužitelju.

Iz dosadašnjeg teksta može se zaključiti da su se evidencije vodile na neadekvatan način iako je informatizacija u DAPA bila na standardnoj razini. ${ }^{25}$ Neke evidencije vodile su se u konvencionalnom obliku (kao knjige u koje se ručno unose podaci), a neke u elektroničkom obliku (podaci su se unosili u radne listove programa Microsoft Excel). Naravno da je zbog takvog načina vođenja evidencija dolazilo do problema. Premda je papir donekle siguran medij i nije problem evidentirati podatke na papir, bilo je znatno otežano pretraživanje podataka. Kod konvencionalnog načina vođenja evidencija dolazilo je i do dupliranja podataka u evidencijama budući da su evidencije na neki način povezane, pa se tako može dogoditi da se u različitim evidencijama unosi sličan ili isti set podataka. Zbog različitih načina vođenja evidencija događalo se da su podaci u jednoj evidenciji ažurirani, a u drugoj ne, te je dolazilo do krivog tumačenja podataka. Prema Pravilniku svaka radnja nad bilo kojim zapisom u evidencijama treba biti zabilježena, čak i ako se evidencije vode elektronički. Elektronički način vođenja evidencija ${ }^{26}$ bio je oprečan zakonskim propisima zato što je bilo nemoguće osigurati uvjete iz članka 24. Pravilnika. ${ }^{27}$

\section{Aplikacija »EVIDiS«}

Reorganizacijom poslova u DAPA i osnivanjem novih Odjela i Odsjeka 2010. godine ${ }^{28}$ stečeni su preduvjeti kako bi se u DAPA samostalno izradila aplikacija za vođenje evidencija koja će biti usklađena s člankom 24. Pravilnika. S izradom nove aplikacije koja je

21 U programu Microsoft Excel.

22 U programu Microsoft Excel. Evidencija je sadržavala dva radna lista: za digitalne preslike snimljene u sigurnosne i zaštitne svrhe i za digitalne preslike snimljene u dopunske svrhe.

23 Navedena mapa bila je dostupna samo djelatnicima u domeni DAPA na poslužitelju, odnosno djelatnicima koji su tada radili u zgradi na adresi Vladimira Nazora 3.

24 U programu Microsoft Excel.

25 Djelatnici DAPA u obavljanju svakodnevnih poslova koriste računalo.

26 U programu Microsoft Excel.

27 Članak 24. Pravilnika glasi: »Evidencije iz ovoga Pravilnika koje se vode u elektroničkom obliku moraju biti zaštićene od neovlaštenog unosa, brisanja, izmjene, pristupa i upotrebe podataka autorizacijom pristupa, evidentiranjem odgovornosti za unos i promjenu podataka i redovitim sigurnosnim kopiranjem.«.

28 Statut Državnog arhiva u Pazinu, KLASA: 012-03/08-01/01, URBROJ: 2163-56-09-01-04 od 20. stude$\operatorname{nog} 2009$. 
nazvana »EVIDiS«, Aplikacija za vođenje evidencija DAPA (dalje: aplikacija) započeto je 2011. godine. Za izradu aplikacije korištene su otvorene i besplatne tehnologije: skriptni jezik $P H P^{29}$ i baza podataka $M y S Q L^{30}$. Aplikacija je dostupna preko mrežnih stranica, a djelatnici DAPA joj pristupaju s bilo koje lokacije ${ }^{31}$ preko mrežnog preglednika kao što su Google Chrome ${ }^{32}$ ili Mozilla Firefox ${ }^{33}$. U 2011. godini su tako izrađene Knjiga akvizicija, Knjiga depozita, Evidencija korisnika i Evidencija korištenog gradiva, a u 2012. godini Opći inventar, Knjiga snimljenoga gradiva, Knjiga dopunskih preslika, Knjiga restauriranoga gradiva i Evidencija stvaratelja. Uz navedene evidencije, 2012. godine izrađene su i spremišne evidencije: Evidencija temperature $i$ vlažnosti u spremištu, Katastik arhivskog gradiva i Katastik mikrofilmova, te pomoćna evidencija Evidencija posjeta. U aplikaciju je uključena ili ručno unesena većina podataka iz evidencija koje su se ranije vodile u Microsoft Excel-u. Na sastanku djelatnika održanog krajem 2012. godine imenovani su djelatnici koji će biti odgovorni za unos podataka u evidencije ${ }^{34}$. Godine 2013. uz evidencije koje su bile izrađene u 2012. godini dovršena je izrada Evidencije imatelja ${ }^{35}$ te pomoćnih evidencija: Digitalno gradivo (pregled digitaliziranog arhivskog gradiva unutar Knjige snimljenoga gradiva i Knjige dopunskih preslika), Pomoćni izvori i Prijedlozi za restauraciju. Izrađena je također i grafička statistika podataka koja se generira automatski iz unesenih podataka u evidencije, te je omogućen unos podataka za arhivske fondove/zbirke prema arhivističkoj normi ISAD $(\mathrm{G}),{ }^{36}$ opis stvaratelja prema arhivističkoj normi ISAAR(CPF ${ }^{37}$ te opis imatelja prema arhivističkoj normi ISDIAH ${ }^{38}$. DAPA je 2. siječnja 2013. omogućen pristup aplikaciji »EVIDiS $\ll{ }^{39} \mathrm{U}$ 2014. godini nastavljen je rad na migraciji podataka i obavljene su izmjene u postojećim evidencijama, pa su u aplikaciju dodane sljedeće pomoćne evidencije: Upisnik obavijesnih pomagala, Aktivna obavijesna pomagala (pregled), Obavijesna pomagala u izradi, Upisnik dosjea fondova, Posudba dosjea fondova, Eviden-

${ }_{29}$ PHP je skriptni jezik koji se izvodi na poslužiteljskoj strani (engl. server-side), a koristi se za kreiranje dinamičkih i interaktivnih web aplikacija, dostupan na http://php.net/ (26.2.2018.).

$30 \quad M y S Q L$ je besplatan sustav (engl. open source) za upravljanje bazom podataka, dostupan na http://www. mysql.com (26.2.2018.).

31 Na ovaj način riješen je problem dostupnosti evidencija budući da djelatnici DAPA, osim u zgradi na adresi Vladimira Nazora 3 rade i u dislociranoj zgradi na adresi Trg Istarskog razvoda 2.

32 Google Chrome internetski je preglednik dostupan na http://www.google.com/intl/hr_HR/chrome/ (26.2.2018.)

33 Mozilla Firefox internetski je preglednik dostupan na http://www.mozilla.org/hr/firefox/ (26.2.2018.)

34 Službena zabilješka od 3. prosinca 2012.

35 Evidencija imatelja i Evidencija stvaratelja vode se u Nacionalnom arhivskom informacijskom sustavu, a uneseni podaci migriraju se prema potrebi u aplikaciju.

36 Opća međunarodna norma za opis arhivskoga gradiva. Dostupno na: http://arhinet.arhiv.hr/_Download/ PDF/ISAD_(G)_2_Izd_Hrv.pdf (26.2.2018.)

37 Međunarodna norma Arhivističkog normiranog zapisa za pravne i fizičke osobe te obitelji. Dostupno na: http://arhinet.arhiv.hr/_Download/PDF/ISAAR(CPF)_2_Izd_Hrv.pdf (26.2.2018.)

38 Međunarodna norma za opis ustanova s arhivskim gradivom. Dostupno na: http://arhinet.arhiv.hr/_ Download/PDF/ISDIAH.pdf (26.2.2018.)

39 Sve evidencije propisane Pravilnikom koje su se do navedenog datuma vodile u konvencionalnom obliku ili elektronički u programu Microsoft Excel vode se preko »Aplikacije za vođenje evidencija «, a dosadašnje evidencije su zaključene i pohranjene. 
cija o posuđenom gradivu iz spremišta i Evidencija zahtjeva. U 2015. godini grafički je oblikovana aplikacija, izrađen je novi dizajn, te su provedene izmjene u postojećim evidencijama. U 2016. i 2017. godini i dalje se radilo na izmjenama i nadogradnjama evidencija u aplikaciji. Na slici 2. prikazan je ukupan broj unesenih zapisa u evidencijama zaključno s 26. veljače 2018 .

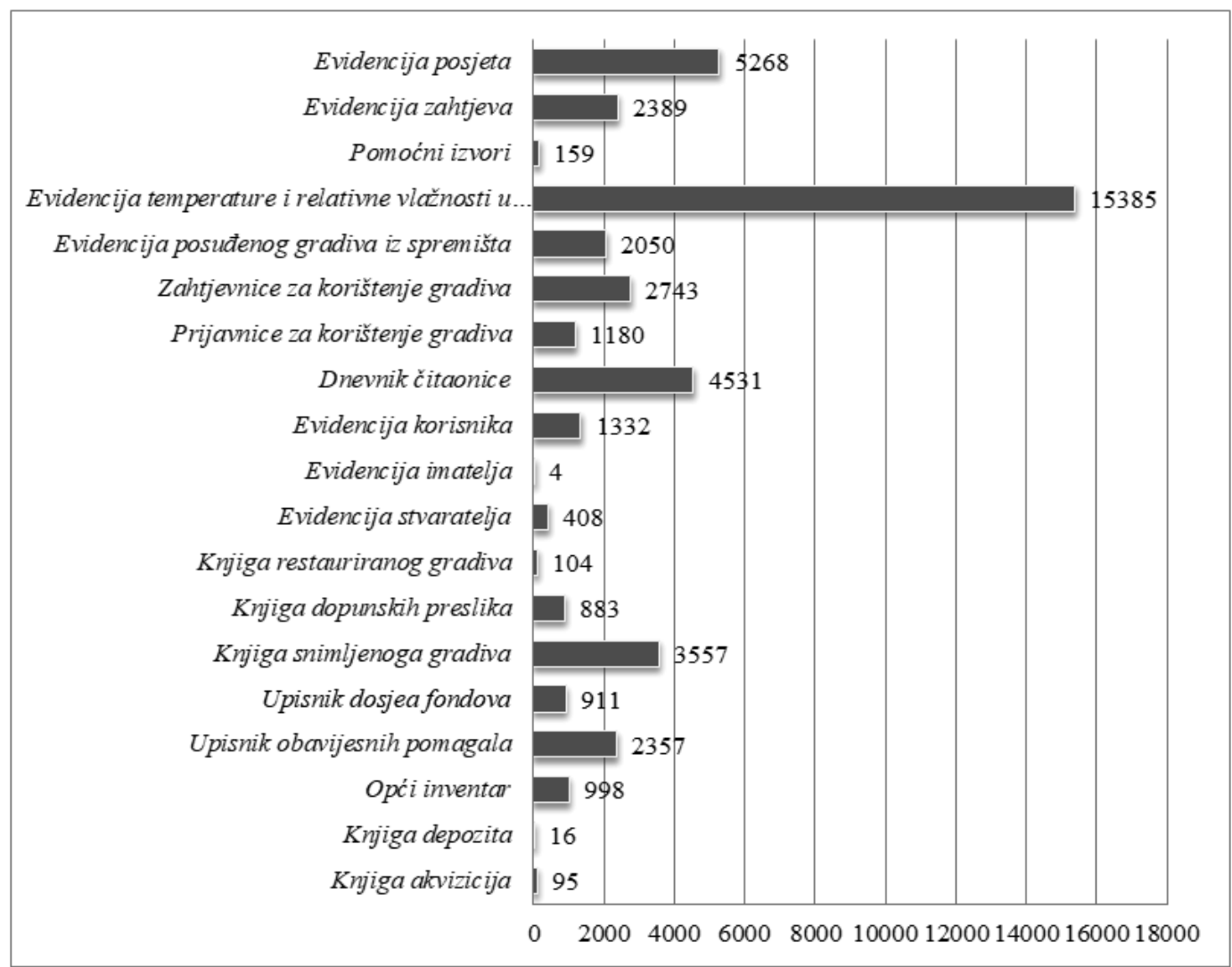

Slika 2. Ukupan broj zapisa po evidencijama u aplikaciji »EVIDiS« do 26. veljače 2018. godine

Način rada u aplikaciji je vrlo jednostavan. Djelatnici DAPA prijavljuju se sa svojim korisničkim imenom i lozinkom (slika 3.). Nakon uspješne prijave prikazuje se početna stranica (slika 4.). Za rad u aplikaciji djelatnicima se dodjeljuju ovlasti administratora ili korisnika. Administrator ima ovlasti za unos, izmjenu/ažuriranje, brisanje, pregled, te pretraživanje podataka o korisnicima aplikacije, dodjeljuje ovlasti (za unos, izmjenu/ažuriranje, brisanje, pregled) nad pojedinim zapisima svakom korisniku, unos, izmjenu/ažuriranje, brisanje, pregled $i$ ispis, te pretraživanje podataka u svim evidencijama i šifrarnicima, pregled grafičkih podataka (statistika), te pregled svih radnji korisnika. Korisnik ima ovlasti za unos, izmjenu/ažuriranje, brisanje, pregled i ispis, te pretraživanje vlastitih zapisa u 
svim evidencijama i šifrarnicima, pregled $i$ ispis, te pretraživanje zapisa drugih korisnika u svim evidencijama i šifrarnicima, te pregled grafičkih podataka (slika 5.). Važno je napomenuti da se inkrementalno sigurnosno kopiranje podataka u aplikaciji obavlja dnevno na serveru pružatelja web hosting usluga s kojim DAPA ima ugovor. ${ }^{40}$

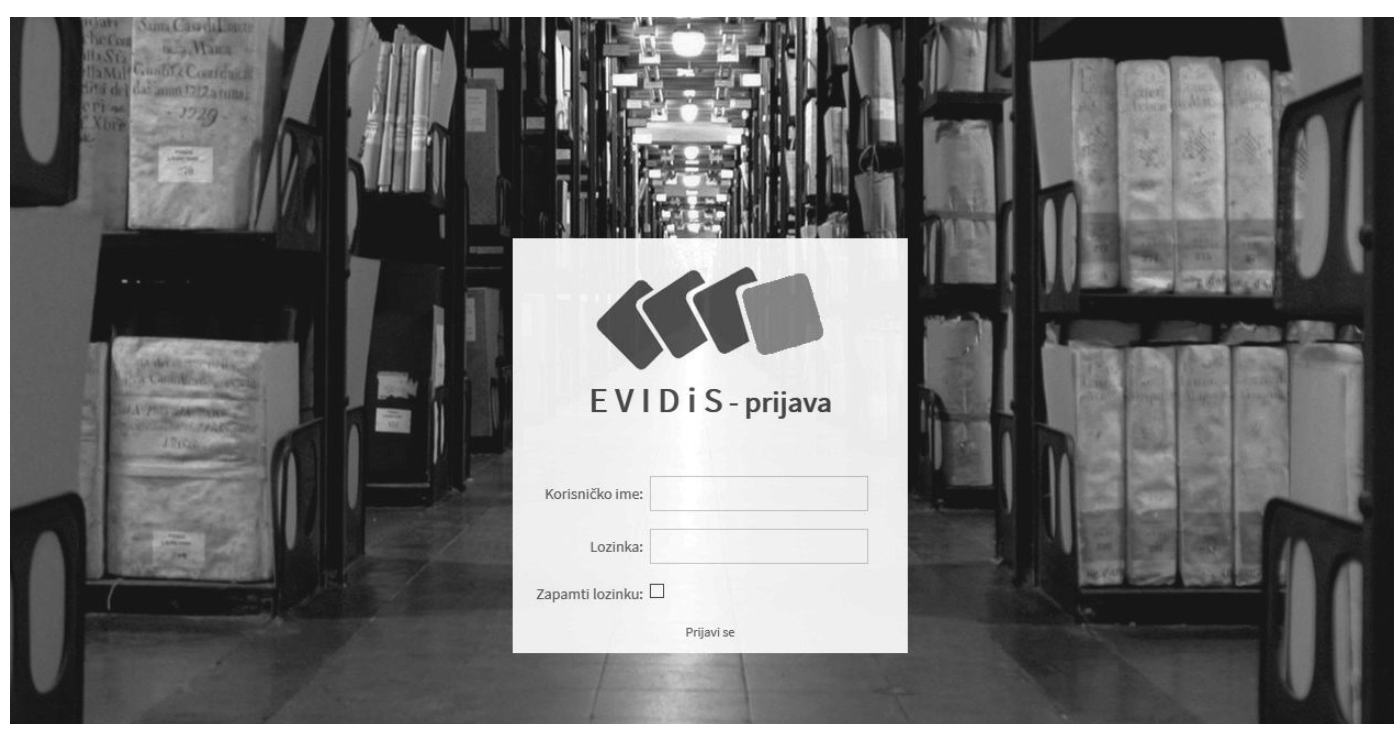

Slika 3. Prijava u aplikaciju »EVIDiS«

\begin{tabular}{|c|c|c|c|c|}
\hline \multicolumn{3}{|c|}{$\begin{array}{l}\text { OPĆI INVENTAR (NASASTAR) ARHIVSKOGA GRADIVA } \\
\text { Popis arhivskih fondova i zbirki u arhivu }\end{array}$} & Korisnik: Legović Sebastijan [Odjel za dokumentacijsko-informacijske poslove s Knjižnicom] & Odjava \\
\hline pretraži & & a & Pronadeno: 998 Stranica 1 od 67 & $15 \sim$ \\
\hline $\begin{array}{l}\text { T) proširi sve } \\
\text { I Knnijga akvizicija / depozita: }\end{array}$ & Dodati novi Napred & Napredno pretraživanje & \multicolumn{2}{|l|}{ DAPA u ukupno 976 arhivskih fondova/zbirki skrbi za $4497.09 \mathrm{~d} /$ m arhivskog gradiva. } \\
\hline$\boxplus$ Opấ inventar: & $\square$ signatura & Naziv fonda/zbirke & \multicolumn{2}{|l|}{ Vremenski raspon cjeline gradiva } \\
\hline \multirow{7}{*}{ 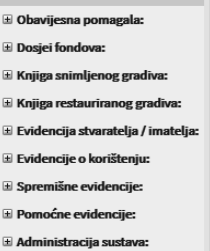 } & $\square$ HR-DAPA-1 & Općina Buje & \multicolumn{2}{|l|}{$1608 / 1784$} \\
\hline & $\square$ HR-DAPA-2 & Općina Labin & \multicolumn{2}{|l|}{ 1420/1797 } \\
\hline & $\square$ HR-DAPA-3 & općina Motovun & \multicolumn{2}{|l|}{$1652 / 1792$} \\
\hline & 国 $\square$ HR-DAPA-4 & Općina Novigrad & \multicolumn{2}{|l|}{ 1471-1797 } \\
\hline & $\square$ HR-DAPA-5 & Općina Poreč & \multicolumn{2}{|l|}{ 1444/1797 } \\
\hline & $\square$ HR-DAPA-6 & Bilježnici Labina i Plomina & \multicolumn{2}{|l|}{$1525 / 1797$} \\
\hline & $\square$ HR-DAPA-7 & Bilježnici Novigrada & \multicolumn{2}{|l|}{$1679-1797[1798-1806]$} \\
\hline & $\square$ HR-DAPA-8 & Bilježnici Poreča & $1433 / 1820[1821 / 1841]$ & \\
\hline & $\square$ 国-DAPA-9 & Bilježnici Vodnjana & $1616 / 1797[1797-1821]$ & \\
\hline & $\square$ HR-DAPA-10 & Rašporski kapetanat & 1394/1797 [1791/1810] & \\
\hline & $\square$ HR-DAPA-11 & Feudalna uprava Završsje & $1557 / 1797[1797 / 1874]$ & \\
\hline & $\square$ HR-DAPA-12 & Pazinska knežija & $1571 / 1918$ [1919/1934] & \\
\hline & [a $\square$ HR-DAPA-13 & PRAZNA (vidi napomenu) & & \\
\hline & $\square$ HR-DAPA-14 & Općina Buje & $1801 / 1805$ & \\
\hline & $\square$ HR-DAPA-15 & Općina Labin & $1802 / 1805$ & \\
\hline & \multicolumn{4}{|c|}{ 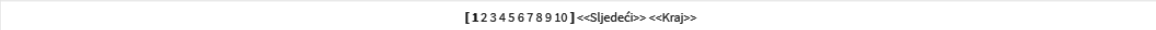 } \\
\hline
\end{tabular}

Slika 4. Početna stranica u aplikaciji »EVIDiS«

40 U skladu s člankom 24. Pravilnika. Na istom se serveru pružatelja web hosting usluga nalaze i internetske stranice DAPA, te internetske stranice Istarskog arhivističkog društva. 
S. LEGOVIĆ, Informatizacija arhivskih evidencija u Državnom arhivu u Pazinu / VIA svezak 25

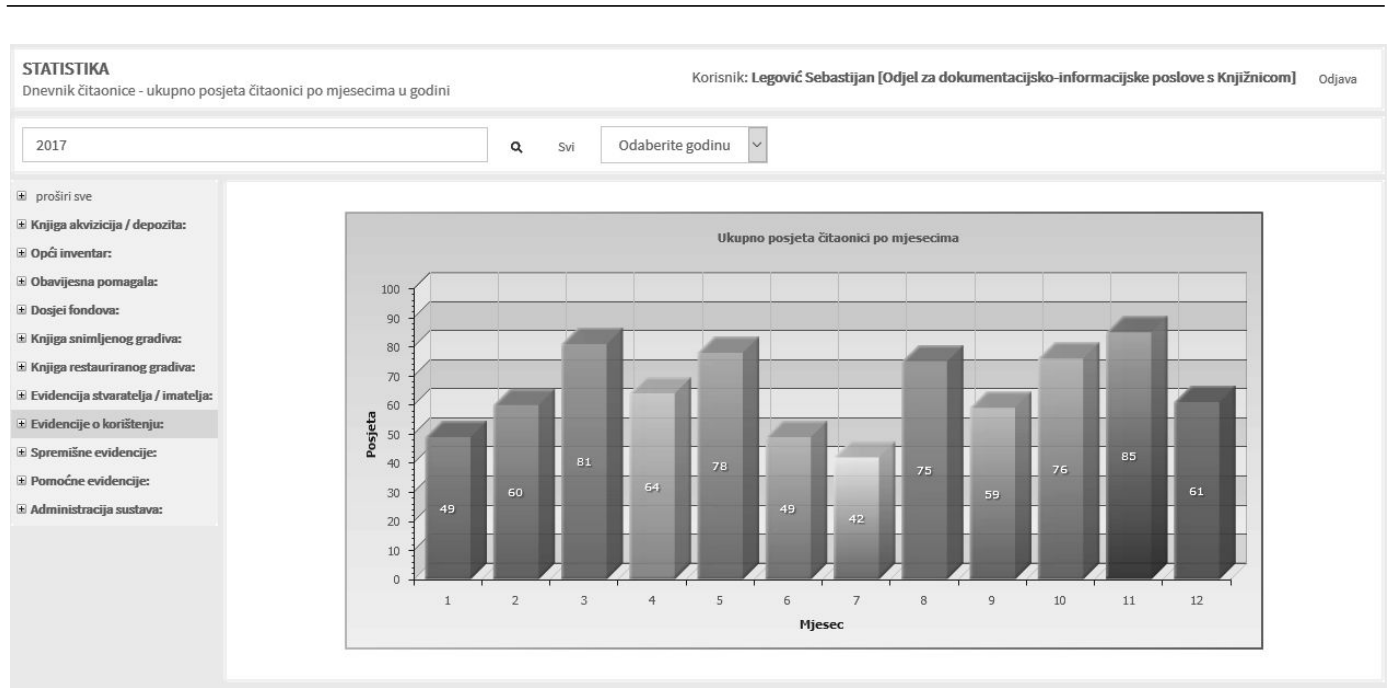

Slika 5. Primjer grafičkog prikaza podataka - ukupno posjeta čitaonici po mjesecima u 2017. godini u aplikaciji $\gg E V I D i S \ll$

\section{Zaključak}

Na temelju iznesenih podataka i iskustva od sedam godina rada u razvijenoj aplikaciji, može se zaključiti da vođenje evidencija na ovakav način pruža niz prednosti. Korištenjem otvorenih tehnologija olakšano je održavanje aplikacije i uštede budući da DAPA ne treba plaćati nikakve licence. Radom u aplikaciji, službene evidencije vode se centralizirano na jednom mjestu i dostupne su svim djelatnicima DAPA. Navedeno je bilo vrlo bitno realizirati prilikom osmišljavanja arhitekture aplikacije budući da djelatnici DAPA rade u dvije dislocirane zgrade. Svi podaci i evidencije usklađeni su s trenutnom zakonskom regulativom, a sustavom za upravljanje korisničkim pravima i pravima pristupa pojedinim podacima riješili su se propisani zahtjevi ukoliko se evidencije vode u elektroničkom obliku. Primjenom aplikacije poslovi na vođenju evidencija postali su jednostavniji i brži, a papirologija svedena na minimum. Važno je napomenuti da se aplikacija i dalje razvija i nadopunjava prema korisničkim zahtjevima. Djelatnici DAPA svakodnevno unose podatke u evidencije iz njihovog djelokruga rada. Aplikacija za vođenje evidencija DAPA ponudila je okvir za daljnji napredak u cilju kvalitetne informatizacije i bržeg dolaska do informacija o arhivskom gradivu, kako djelatnicima tako i korisnicima usluga DAPA. 


\section{SAŽETAK}

\section{Informatizacija arhivskih evidencija u Državnom arhivu u Pazinu}

DAPA u okviru svojih djelatnosti obavlja sve stručne poslove vezane uz arhivsko gradivo. Jedan od navedenih poslova je vođenje arhivskih evidencija. Uvidom u evidencije dobivaju se sve informacije vezane uz arhivsko gradivo koje se čuva u DAPA. S poslovima vođenja evidencija započinje se još u šezdesetim godinama prošlog stoljeća. Evidencije su se vodile u konvencionalnom obliku, odnosno ručnim unosom podataka u knjige. Pojavom osobnih računala i njihovom sve većom uporabom, već se $u$ devedesetima pokušalo uvesti informatizirani način vođenja evidencija. Gledalo se iskoristiti prednosti informatizacije budući da se uporabom računalnih tehnologija brže dolazilo do traženih informacija i stvaralo puno manje papirologije. Novim Zakonom o arhivskom gradivu i arhivima iz 1997. i Pravilnikom o evidencijama u arhivima iz 2002. godine (i njihovim kasnijim izmjenama i dopunama) propisano je vođenje svih službenih evidencija u arhivu, a po prvi puta je propisan i način vođenja evidencija u elektroničkom obliku. Zbog više objektivnih razloga, poslovi vođenja evidencija u DAPA u skladu s novim propisima započinju tek 2004. godine. Uz evidencije koje su se i dalje vodile u konvencionalnom obliku, pokušalo se iskoristiti sve podatke koji su se radom na različitim poslovima evidentiranja već nalazili u elektroničkom obliku. Narednih godina su se skoro sve evidencije vodile u elektroničkom obliku. Godine 2011. započinje razvoj aplikacije »EVIDiS« za centralizirano vođenje svih evidencija. Odlučeno je da se aplikacija izradi na način da podaci u evidencijama budu dostupni preko mrežnih stranica budući da djelatnici DAPA rade u više zgrada. Odabir otvorenih tehnologija pri izradi aplikacije pružio je niz prednosti, a smanjili su troškove izrade i kasnijeg održavanja. Aplikacija »EVIDiS« omogućava vođenje svih evidencija u skladu s trenutnom zakonskom regulativom. Danas se i dalje ažurno vode sve propisane evidencije i pomoćne evidencije, a retroaktivno se unose podaci temeljem dokumentacije koja se prikuplja kontinuirano.

\section{SUMMARY}

\section{Informatization of archive records in the Pazin State Archives}

In the course of its activities, DAPA performs all professional services related to archival material. One of such tasks is keeping archive records. All information related to archival material kept in DAPA can be obtained by inspecting these records. The records keeping services were introduced as early as in the 1960s. Records were kept conventionally, based on manual entry of data into books. Folloing the appearance of personal computers and their increasing use, attempts towards a computerized way of keeping records were made in the 1990s. Endeavours were made to take advantage of the benefits of computerization, as using computer technology provided a faster way to access required information 
and created much less paperwork. The new 1997 Archives and Archival Institutions Act and the 2002 Ordinance on Record Keeping in Archives (and their subsequent amendments) prescribed the keeping of all official records in the archives, and for the first time the keeping of records in electronic form was laid down. Due to several objective reasons, DAPA started records keeping operations in accordance with the new regulations only in 2004. Along with records keeping that continued to be in the conventional form, endeavourse were made to use all the information that was already made in electronic form as part of different recording. In subsequent years, almost all records were kept in electronic form. The year 2011 saw the commencement of development of the "EVIDiS" application for the centralized keeping of all records. It was decided that the application should be made so that data about the records can be accessed through the web pages considering that DAPA employees work in multiple buildings. The choice of open technologies in designing the application has provided a number of benefits, reducing the cost of production and subsequent maintenance. The "EVIDiS" application allows to keep all records in accordance with current legal regulations. Today, all prescribed records and ancillary records are maintained up-to-date, whil data is entered retrospectively based on the documentation that is continuously collected.

\section{RIASSUNTO}

\section{Informatizzazione delle registrazioni archivistiche nell'Archivio di Stato di Pisino}

L'ASP/DAPA, nell'ambito delle sue attività, esegue tutti i lavori tecnici relativi al materiale archivistico. Tra i lavori citati c'è anche la registrazione archivistica. Consultando i registri cronologici si ricavano tutte le informazioni relative al materiale archivistico conservato nell'ASP. L'inizio delle registrazioni archivistiche risale già agli anni 60 dello scorso secolo. La registrazione veniva effettuata in modo convenzionale, valle a dire tramite l'inserimento manuale dei dati nei libri. Con l'arrivo dei computer personali e con la loro diffusione, già negli anni 90 c'è stato un tentativo di introdurre il metodo computerizzato nella registrazione. Si è cercato di usare i vantaggi dell'informatizzazione dato che con l'utilizzo di tecnologie informatiche l'accesso alle informazioni richieste era più veloce $\mathrm{e}$ si risparmiava un sacco di scartoffie. Con la nuova Legge sul materiale archivistico e sugli archivi del 1997 e con il Regolamento sulle registrazioni negli archivi del 2002 (e con le successive modifiche e aggiunte) sono state definite le modalità per effettuare tutte le registrazioni ufficiali nell'archivio, e per la prima volta sono state definite le modalità per effettuare le registrazioni in forma elettronica. Per vari motivi oggettivi, i lavori di registrazione nell'ASP in conformità ai nuovi regolamenti iniziano appena nel 2004. Oltre alle registrazioni che venivano effettuate ancora in modo convenzionale, si è cercato di utilizzare tutti i dati emersi da diversi lavori di registrazione che erano già in forma elettronica. Negli anni successivi quasi tutte le registrazioni venivano effettuate in modo elettronico. Nel 2011 inizia lo sviluppo dell'applicazione „EVIDiS“ per l'effettuazione della registra- 
zione centralizzata. È stato deciso di creare l'applicazione che rendesse disponibile i dati nelle registrazioni tramite il sito web dato che i dipendenti dell'ASP lavorano in strutture diverse. La scelta delle tecnologie aperte nella creazione dell'applicazione ha prodotto molti vantaggi ed ha diminuito le spese nella realizzazione e nella successiva manutenzione. L'applicazione „EVIDiS“ rende possibile l'amministrazione di tutte le registrazioni in conformità alle regolative vigenti. Oggi continuano ad effettuarsi regolarmente tutte le registrazioni previste nonché quelle ausiliari, e, in modo retroattivo, vengono inseriti i dati in base alla documentazione che viene raccolta continuamente. 